\title{
Molecular identification of larvae for Anisakidae family re- duced in benthic and pelagic fish
}

Maria Drussilla Buscemi, Francesca Ornella Assiria, Francesco Giuseppe Galluzzo,Viviana Giangreco, Ilaria Rizzuto, Gaetano Cammilleri, Rosaria Collura, Stefania Graci, Valentina Cumbo, Antonio Spinnato, Gianluigi Maria Lo Dico \& Vincenzo Ferrantelli

Centro di Referenza Nazionale per le Anisakiasi, Istituto Zooprofilattico Sperimentale della Sicilia “A. Mirri”, Via G. Marinuzzi 3, 90129 Palermo, Italy

\begin{abstract}
S The present work, carried out at the Istituto Zooprofilattico Sperimentale della Sicilia “A.Mirri”, Department of Food, Laboratory C.Re.NA (National Reference Center for Anisakiasis), aims to identify species of larvae found in different fish species from the pelagic and benthic environment through molecular analysis (PCR, PCR-RFLP and sequencing) and evaluate the possible ecological relationship between parasites and guests in the two different marine environments.
\end{abstract}

KEY WORDS

Anisakidae; PCR-RFLP; benthic; pelagic.

Received 22.11.2019; accepted 10.12.2019; published online 20.12.2019

Proceedings of the 4th International Congress on Biodiversity "Man, Natural Habitats and Euro-Mediterranean Biodiversity", November 17th-19th, 2017 - Malta

\section{INTRODUCTION}

In the last ten years, there was an increase in the consumption of raw fish due to the introduction of new eating habits from countries outside Europe (sushi, sashimi, herring, pickled anchovies, etc.), increasing the risk of contracting parasitic diseases, such as Anisakiasis (Audicana et al., 2002). Anisakiasis is a disease caused by nematodes of the genus Anisakis, belonging to the Anisakidae family, together with Pseudoterranova, genera (Køie et al., 1995; Pozio, 2013). Human infestation occurs by ingestion of third stage Anisakis larvae present in raw fish and cephalopods but also undercooked, marinated, pickled, smoked or salted. These parasites are found, at the adult stage, in the abdomen of marine mammals (whales, seals, dolphins), more precisely in the stomach where they are visible to the naked eye. In fish, which are intermediate hosts, the larval form are normally found in the coelomic cavity where they can found free or encysted or adherent to the various organs and tissues (Mattiucci $\&$ Nascetti, 2008). In the present study larval forms of Anisakidae collected in pelagic, benthic and demersal fishes sampled in Sicily were identified by molecular analysis according to the protocols reported in literature (Cavallero et al., 2015).

\section{MATERIAL AND METHODS}

Detected larvae are subjected to identification at genus level, through the optical microscopy (Leica DM 2000), according to morphological characters (Berland, 1961). Subsequently, the larvae were washed, fragmented with a scalpel and frozen at $20{ }^{\circ} \mathrm{C}$ for 24 hours. The extraction of DNA were conducted by special kits based on the use of affin- 


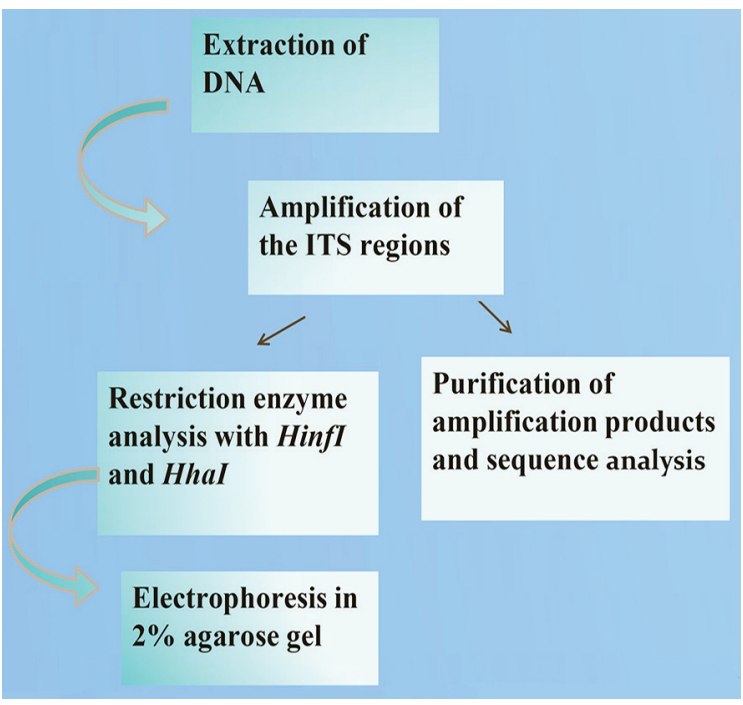

Figure 1. Molecular identification.

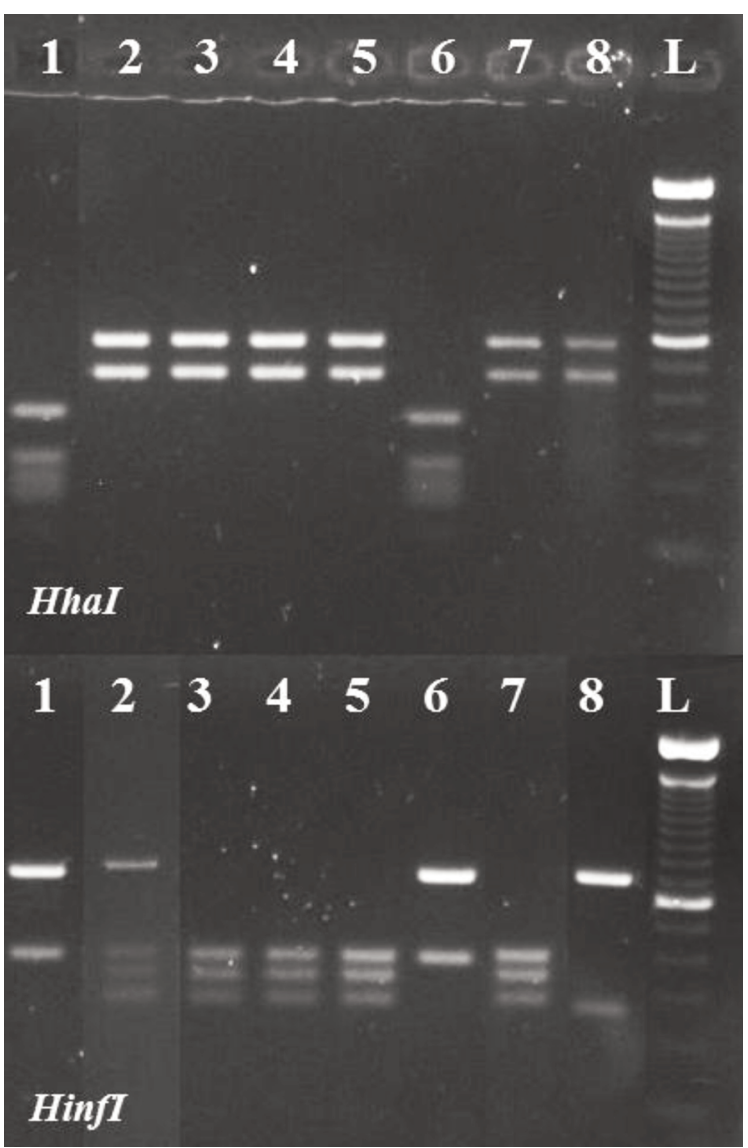

Figure 2. Restriction enzyme analysis with HinfI and HhaI Lane 1-6: Anisakis typica; lane 2: Anisakis simplex s.s./Anisakis pegreffii hybrid form; lane 3-4-5-7: Anisakis pegreffii; lane 6: Anisakis simplex s. s.; L: ladder 100 bp. ity columns. For the genus Anisakis we proceeded to the amplification of the ITS regions (ITS-1, ITS2 and $5.8 \mathrm{~S}$ subunit) of nuclear rDNA by the primers NC5 (5'GTA GGT GAA CCT GCG GAA GGA TCA TT3'), NC2 (5'TTA GTT TCT TTT CCT CCG CT3') (Zhu et al., 1998). The DNA samples have been subjected to restriction enzyme analysis with two restriction enzymes, HinfI and HhaI, for the identification of Anisakis spp. according to genetic key of D'Amelio et al. (2000). The digestion was performed over night at $37^{\circ} \mathrm{C}$ and the digestion products were electrophoresed in $2 \%$ agarose gel (Invitrogen) stained with SYBR safe ${ }^{\circledR}$ and visualized by UV transilluminator (Figs. 1, 2). For the identification of Hysterothylacium species a sequence analysis were conducted. Purification of ITS gene amplification products was carried out with Illustra GFX PCR DNA and Gel Band Purification kit (GE Healthcare) following the manufacturer's instructions. The purified products were sent to Macrogen company (Amsterdam, Holland) for Sanger sequencing (Fig. 3).

\section{RESULTS AND DISCUSSION}

In the seas surrounding Sicily the larvae found in the various species of fish belonged to the Anisakis and Hysterotilacium genera of the Fischer Anisakidae. The pelagic environment was rich in larvae belonging to the Anisakis genus such as Anisakis pegreffii, Anisakis simplex s.s. as well as the hybrid species Anisakis pegreffii / Anisakis simplex s.s. In the benthic environment predestined species belonging to the genus Hysterotilacium there was also a low presence of larvae of the species Anisakis pegreffii. Demersal fish species were found infested both by Hysterotilacium aduncum and by Anisakis pegreffii. The data obtained indicate a different parasites belonging to the Anisakidae family as well as the fish species of pelagic and benthic marine environments, indicating therefore a difference of infestation in relation to the different habitats (Fig. 4).

\section{REFERENCES}

Audicana M.T., Ansotegui I.J., de Corres L.F. \& Kennedy M.W., 2002. Anisakis simplex: dangerous-dead and 


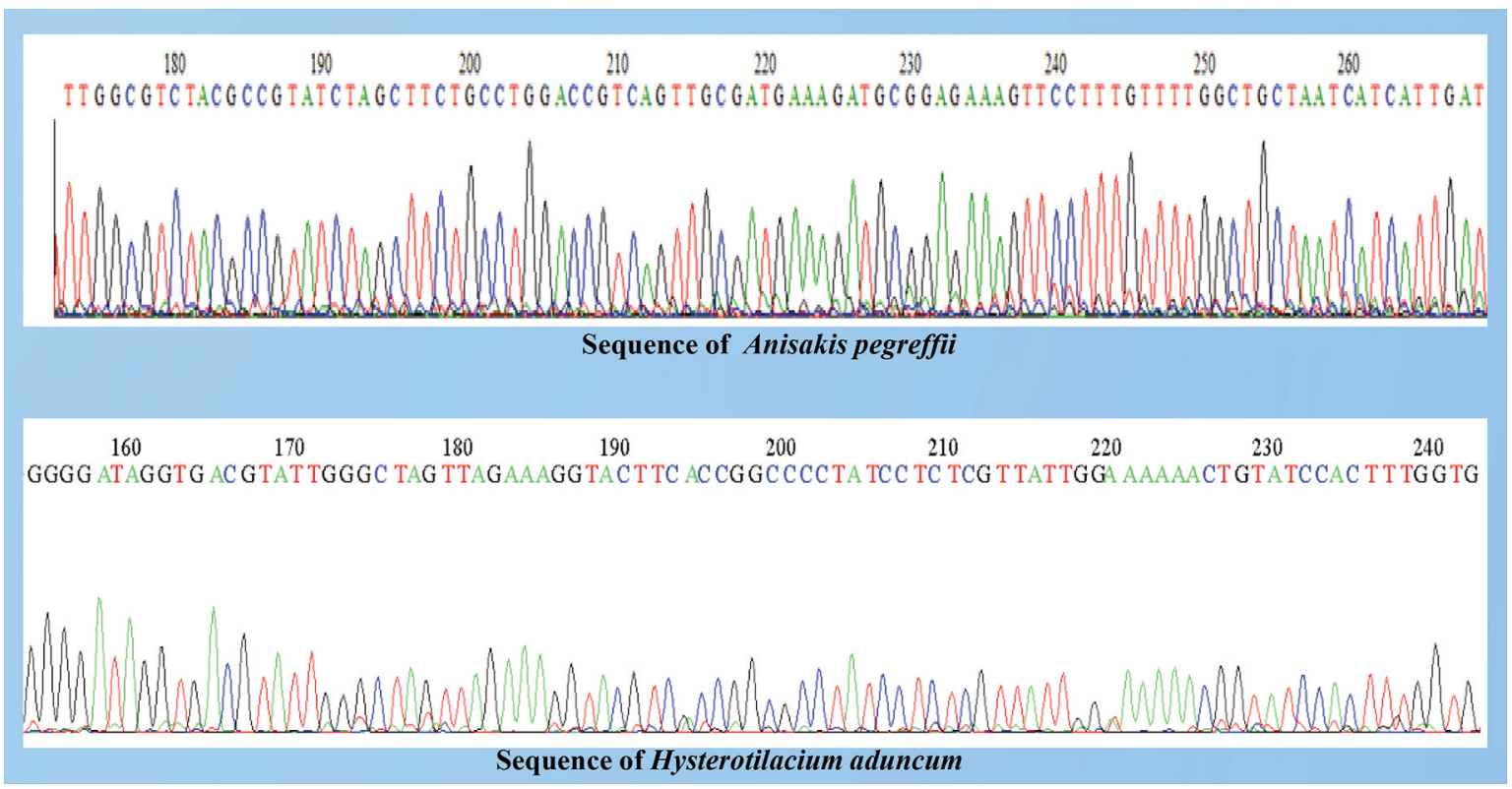

Figure 3. Sanger sequencing.

\begin{tabular}{|c|c|c|c|c|c|c|}
\hline & Species & $\begin{array}{c}n . \\
\text { guests }\end{array}$ & n. larvae & Larvae species & zone F.A.O. & \\
\hline $\begin{array}{l}\text { Pelagic } \\
\text { environment }\end{array}$ & $\begin{array}{l}\text { Sgomber sgombrus } \\
\text { Engraulis encrasicolus } \\
\text { Sardina pilchardus }\end{array}$ & 289 & 259 & $\begin{array}{c}\text { A. pegreffii } \\
\text { A. simplex } \\
\text { A. pegreffii/A. } \\
\text { simplex }\end{array}$ & $\begin{array}{c}37.12 \\
37.19 \\
37.15 \\
27 \\
\end{array}$ & $\begin{array}{c}T P \\
M E \\
S R \\
\text { Atlantic }\end{array}$ \\
\hline $\begin{array}{l}\text { Benthic } \\
\text { environment }\end{array}$ & $\begin{array}{l}\text { Mullus barbatus } \\
\text { Scorpaena scrofa }\end{array}$ & 29 & 8 & $\begin{array}{l}\text { H. aduncum } \\
\text { A. pegreffii }\end{array}$ & $\begin{array}{l}37.16 \\
37.15\end{array}$ & $\begin{array}{l}A G \\
S R\end{array}$ \\
\hline Demersal & $\begin{array}{l}\text { Merlucius merlucius } \\
\text { Lepidopus caudatus }\end{array}$ & 9 & 604 & $\begin{array}{l}\text { A. pegreffii } \\
\text { H. aduncum }\end{array}$ & 37.12 & TP \\
\hline Total & & 327 & 871 & & & \\
\hline
\end{tabular}

Figure 4. Larvae of Anisakidae family found in bentonic and pelagic fish.

alive? Trends in Parasitology, 18: 20-25. http://dx. doi.org/10.1016/s1471-4922(01)02152-3

Berland B., 1961. Nematodes from some Norwegian marine fishes. Sarsia, 2: 1-50. http://dx.doi.org/10.1080/ 00364827.1961 .10410245

Cavallero S., Magnabosco C., Civettini M., Boffo L., Mingarelli G., Burattic P., Giovanardi O. \& Fortuna C. M., 2015. Arcangeli G. Survey of Anisakis sp. and Hysterothylacium sp. in sardines and anchovies from the North Adriatic Sea. International Journal of Food Microbiology, 200: 18-21.

D’Amelio S., Mathiopoulos K.D., Santos C.P., Pugachev
O.N., Webb S.C., Picanço M. \& Paggi L., 2000. Genetic markers in ribosomal DNA for the identification of members of the genus Anisakis (Nematoda: Ascaridoidea) defined by polymerase-chain-reactionbased restriction fragment length polymorphism. International Journal of Parasitology, 30: 223-226. http://dx.doi.org/10.1016/S0020-7519(99)00178-2

Køie M., Berland B. \& Burt M.D.B., 1995. Development to third-stage larvae occurs in the eggs of Anisakis simplex and Pseudoterranova decipiens (Nematoda, Ascaridoidea, Anisakidae). Canadian Journal of Fisheries and Aquatic Sciences, 52: 134-139. 
Mattiucci S. \& Nascetti G., 2008. Advances and Trends in the Molecular Systematics of Anisakid Nematodes, with Implications for their Evolutionary Ecology and Host-Parasite Co-evolutionary Processes. Advances in Parasitology 66: 47-148.

Pozio E., 2013. Integrating animal health surveillance and food safety: the example of Anisakis. Revue sci- entifique et technique, (International Office of Epizootics) 32: 487-496.

Zhu X. Gasser R.B., Podolska M. \& Chilton N.B., 1998. Characterisation of anisakid nematodes with zoonotic potential by nuclear ribosomal DNA sequences fn 1 . International Journal of Parasitology, 28: 1911-1921. http://dx.doi.org/10.1016/S0020-7519(98) 00150-7 